\title{
Institutions and national development in Latin America: a comparative study
}

\section{Alejandro Portes* and Lori D. Smith}

Department of Sociology, Princeton University, Princeton, NJ, USA

*Correspondence: port44@princeton.edu

We review the theoretical and empirical literature on the role of institutions in national development as a prelude to presenting a more rigorous and measurable definition of the concept and a methodology to study this relationship at the national and subnational levels. The existing research literature features conflicting definitions of the concept of 'institutions' and empirical tests based mostly on reputational indices, with countries as units of analysis. The present study's methodology is based on a set of five strategic organizations studied comparatively in five Latin American countries. These include key federal agencies, public administrative organizations and stock exchanges. Systematic analysis of results shows a pattern of differences between economically oriented institutions and those entrusted with providing basic services to the general population. Consistent differences in institutional quality also emerge across countries, despite similar levels of economic development. Implications of the results for theory and for methodological practices of future studies in this field are discussed.

Keywords: institutions, development, organizations, Latin America, Boolean algebra

JEL classification: R11 regional economic activity, growth, development, and changes

\section{Introduction}

The study of development in economics has been revolutionized in recent years by a new perspective that replaced the old neo-classical consensus on the primacy of free markets and capital stocks. This perspective pivots around the concept of 'institutions', a familiar term in sociology but something of a novelty in mainstream economics, which had largely abandoned the institutionalist tradition. It took the influence of two Nobel prizes, awarded Douglass North first and Joseph Stiglitz later, to accomplish the feat of swaying the obdurate belief in 
markets. When North declared that 'institutions matter', they actually started being taken into account.

By their own light and paying little attention to its sister disciplines, economists 'brought the state back in' the analysis of national development, highlighting the importance of such things as 'good governance' (La Porta et al., 1999; Rodrik et al., 2002) and bureaucratic 'quality' (Rauch, 1995). Sociologists and other social scientists welcomed this 'institutional turn' as a re-vindication of their own ideas, but with an important omission. Swayed by the promise of interdisciplinary collaboration, they overlooked the lack of professional training by economists to deal with the character of institutions or to place the concept in a proper theoretical framework. As Hodgson, an economist himself, noted:

The blindness may be partial, but the impairment is nevertheless serious and disabling. What is meant by this allegation of blindness is that, despite their intentions, many mainstream economists lack the conceptual apparatus to discern anything but the haziest institutional outlines... [they] have not got adequate vision tools to distinguish between different types of institutions, nor to appraise properly what is going on in them. (Hodgson, 2002, p. 148)

This state of things has had two important consequences. First, a neglect of real functioning institutions in favour of aggregate reputational indices. Compiled by international agencies, such as the World Bank or commercial 'country risk' companies, these indices yield a single score per country. This approach neglects differences within nations and the complexity of their organizational structures (Evans, 2004b). Reputational scores are also subject to selective bias, as opinions are influenced by the actual economic performance of countries, leading to tautological conclusions (Jutting, 2003).

The second consequence is a state of confusion about the definition of the concept itself. North defined institutions as 'any form of constraint that human beings devise to shape interaction' (North, 1990, p. 3), a vague definition that encompasses everything, from norms introjected during the socialization process to physical coercion. From this statement, all that can be said is that institutions exist when something exerts external influence over social actors, exactly the same notion that Durkheim termed 'norms' more than a century ago. In the current institutions and development literature, we encounter quite different theoretical and operational definitions - ranging from laws to safeguard property rights to meritocratic bureaucracy to actual organizations like central banks. Introducing a helpful review of this literature, Jütting notes:

Quite divergent definitions and concepts of 'institutions' are given, ranging from the narrow definition proposed by North... to 
definitions that include organizational entities. Some of the reviewed studies did not clearly spell out what they understood by 'institution', making judgment of their impact rather difficult. (Jutting, 2003, p. 9)

The purpose of the present study is two-fold: First, bringing sociological theory to bear on this state of affairs in search of a rigorous and measurable definition of the concept of institutions. Second, presenting results of a comparative analysis of real institutions studied with the same methodology in five Latin American countries. The study aims at demonstrating that comparative empirical analysis of such institutions is possible and at exploring differences in the character and performance of the organizations that embody them, not only across countries but within each of them. We seek to restore the value of institutional analysis by problematizing what is now hidden under the rug, namely the potential heterogeneity of institutions within countries and the potential commonalities across them.

\section{The sociological contribution}

Sociologists are not entirely in agreement on the actual meaning of institutions either (Scott, 2001), yet a set of broad understandings have emerged concerning their existence and relative significance. Organizations, economic and otherwise, are what social actors normally inhabit in the routine course of their lives and they embody the most readily visible manifestations of the underlying structures of power (DiMaggio, 1990; Powell, 1990; Scott, 1995). Institutions represent the symbolic blueprint for organizations - they are the set of rules, written or informal, governing relationships among role occupants in organizations like the family, the schools and the other major areas of social life: polity, economy, religion, communications and information and leisure (Maclver and Page, [1949] 1961; Merton, 1968; North, 1990; Hollingsworth, 2002).

The modern sociology of organizations has also focused on the role of institutions as their symbolic counterparts (Scott, 1995). However, the way of relating both concepts has varied significantly. In the classic work of Robert Merton on bureaucracy, institutional blueprints influence bureaucratic officials so much that they transform norms into ends-in-themselves, thus leading to increasing organizational rigidity (Merton, [1940] 1957). The influential analysis by Merton's student, Philip Selznick, of the Tennessee Valley Authority shifted the emphasis towards 'institutionalization' as a process of 'infusing organizations with values' (Selznick, [1949] 1966). Selznick's own students, such as Gusfield (1955) and Stinchcombe (1965), shifted the emphasis again by taking the original institutional rules at face value, but then showing how interaction among social actors changed their meaning and the very goals of the organization.

Portes (2006) highlighted the seriousness of a lack of rigour in the definition of 'institution' in the present economic development literature and sought to 
overcome the problem by situating the term in the conceptual space constructed by classic sociological theory, including elements of both culture and social structure. His schema is reproduced in Figure 1, and his definition of institutions as 'blueprints for organizational behaviour' is the one we use in this study. This definition gives us the necessary leverage to understand phenomena that otherwise would be obscured. In particular, the distinction between organizations and the institutions that govern them provides a basis for comprehending how events in economic life actually unfold. For it is not the case that, once established, role occupants blindly follow institutional rules. As the studies cited previously and others show, actors constantly modify the rules, transform them and even bypass them in the course of their daily interaction.

It is worth highlighting the gap between this sociological perspective, focused on the dynamics of organizations and the unexpected turns that they can take under the influence of human agency, and the definition of institutions in contemporary economics. The latter emphasizes the homogeneity of the state apparatus that, operationally, is often reduced to a single score in a composite index. The sociological contribution is to emphasize gaps between institutional blueprints and actual organizations and the differences among them, determined by history and social context. Organizations vary in the extent to which their practices, activities and routines align with their institutional design in the first place; tax authorities with similar formal designs may vary considerably in

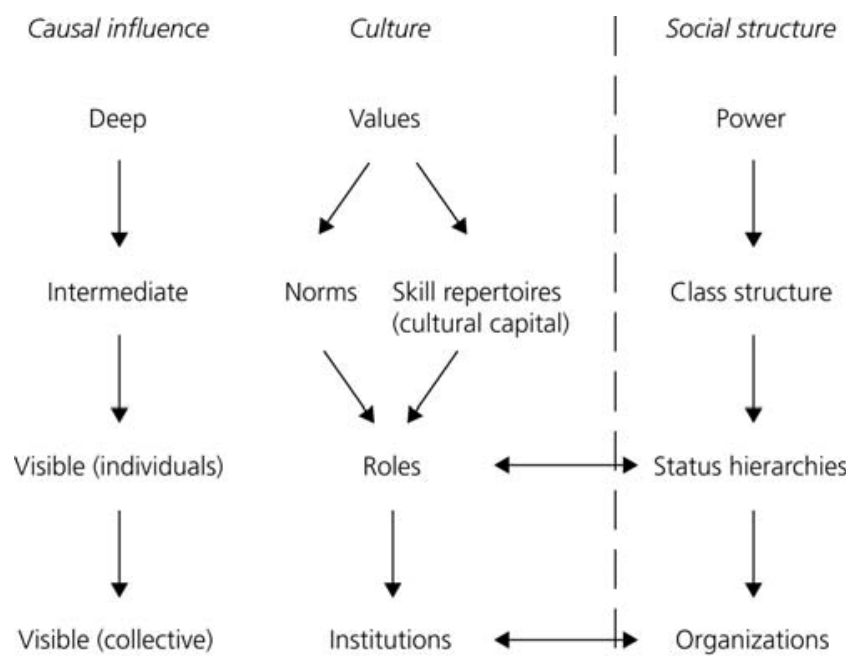

Source: Portes (2006).

Figure 1 The elements of social life and the placement of institutions. 
their actual capacity or ability to collect revenue. As a consequence, it is not enough to estimate the effects of formal institutions on economic performance; rather, it is necessary to consider the forces driving the performance of particular organizations. With this conceptual spadework done, it becomes possible to undertake an empirical analysis of actual institutions.

\section{The 'institutional turn' in development studies: a review}

North's pronouncements were followed by a series of studies, historical and contemporary, on the role of various social forces, collectively lumped under 'institutions', on national development. Among the most influential and original is the study by Acemoglu et al. (2001) that focused on the path dependence of institutions created by Europeans in their areas of concentration. Colonies where Europeans created permanent settlements developed solid institutional frameworks copied from the mother countries, which, in turn, created the basis for sustained economic development. Aware of the perennial endogeneity problem between institutions and development, Acemoglu et al. instrumented their main determinant-European settler concentration-on prior reported death rates among early colonists, soldiers and even bishops. They reasoned that areas where high death rates were reported among early settlers because of malaria and yellow fever were confined to an extractive role and that only healthier ones were conducive to concentrated settlement by Europeans.

Like almost all studies in this field, Acemoglu et al. depend for their measure of institutional quality on reputational indices that assign a single score per country. In their case, they draw on Political Risk Services, Inc. for a measure of 'average protection against expropriation', supplemented by a measure of 'constraints on the executive' taken from the Polity III data by Gurr (1997) (Acemoglu et al., 2001, p. 1378). The industry standard in this field appears to have become the International County Risk Guide (ICRG) compiled by Knack and Keefer (1995). Another important measure is the Rule of Law index employed, among others, in Dollar and Kraly's (2002) influential study. As Jutting (2003, p.19) notes in his review of this literature: "Nearly all the studies use as a proxy for "institutions" variables that measure the quality and performance of institutions rather than the institution itself'. These reputational measures also risk tautology, as noted previously, because the assembled opinions on 'institutional quality' can be influenced by the level of economic development achieved by different countries.

Finally, a debate has been raging between researchers grouped around Dani Rodrik (Rodrik et al., 2002) that stresses the role of institutions as 'trumping everything else' (Jutting, 2003, p. 19) and another group around Jeffrey Sachs (2003) that emphasizes the role of geography, especially distance from the equator. None of these approaches makes allowance for subnational differences in institutional 
performance, nor for the dynamic quality of real-life organizations. The image that emerges from most of this literature is that of a static world with countries frozen in a hierarchy of good governance, indexed by a single number.

A more nuanced, sociological account of the role of institutions on development is provided by Nee and Opper (2009). After carefully building a Weberian ideal type of bureaucracy, they go on to argue that it is the quality of this apparatus, not legal formal protections of shareholders, that fosters long-term capitalist development:

The lower the bureaucratic quality, the higher the level of uncertainty faced by economic actors and the less the calculability in both short and long-term planning.... (Nee and Opper, 2009, p. 299)

To buttress the argument, these authors also rely on an index of 'government effectiveness' compiled by the World Bank (Kaufmann et al., 2005) that, because of its numerous indicators and inclusion of objective measures, is believed to provide 'the least noisy signal of the underlying notion of bureaucratic quality' (Nee and Opper, 2009, p. 301). Not surprisingly, African countries, such as Nigeria, rank at the very bottom of this scale, while the Netherlands and the Scandinavian countries rank at the very top. Predictably, the index has a strong positive 'effect' on capitalistic development.

Reviewing this literature, a strong sense emerges that studies at closer range are needed to develop nuance and bar tautology. It is possible that not all governmental agencies and quasi-governmental institutions in Nigeria are hopeless; nor that all Dutch and Scandinavian ones are paragons of excellence. Moreover, as sociologists of organization have repeatedly noted, these are dynamic entities that change over time and can adapt rather rapidly to shocks and transformations in their environment. Seeking to move beyond the present research literature, we draw on Portes's scheme in Figure 1 to identify a sample of institutions sufficiently important and diverse to tell us something about possible subnational diversity and to clarify the extent to which actual organizations correspond or not to institutional blueprints.

\section{Research design}

For this purpose, we recruited teams of experienced researchers in five countries to conduct year-long studies of target institutions on the basis of a common research design. We selected Latin American countries because of their common historical origins and culture and their comparable levels of development. Our intent was to see whether differences existed between a sample of countries that commonly receive comparable scores in cross-national indices of institutional quality. Specifically, the study sought answers to the following questions: 
1. Whether systematic differences could be uncovered in the developmental contribution of a sample of institutions within the same country and a sample of the same institution across different countries.

2. If such differences could be identified, whether they are due to idiosyncratic characteristics of each country's history and culture or whether common external forces influence them.

3. Whether a common profile of characteristics making up a 'developmental' institutions could be identified in the data.

4. Whether a rank-order could be established among countries, based on the relative presence of such institutions.

\section{Countries and institutions}

The countries included in the study are Argentina, Chile, Colombia, Mexico and the Dominican Republic. Brazil was excluded because of its size and its somewhat different historical origins as a Portuguese colony. The five countries selected cover the geographical length of Latin America, from south to north, and represent a fair sample of the relative levels of development found in the region. There were, in addition, specific theoretical reasons to include each individual country. They are omitted here in the interest of space, but will be raised in the inter-country comparison in response to Question 4 above.

We selected institutions of national scope that differed, in their respective functions, along an axis ranging from 'primarily economic' to 'mostly technical' to 'primarily social'. Most of these were state agencies, although they included an important private entity - the national stock exchange. While the universe of institutions amenable for study is quite large, we believe that those selected are emblematic of economic, technical and social functions deemed fundamental for the proper organization and advancement of most nations. ${ }^{1}$ They are as follows:

Stock exchanges have been studied in the past as the ideal type of unfettered capitalism, evolving in time from closed clubs to regulated entities open to public investment (Weber, [1904] 1949; Abolafia, 1996). Even small nations currently possess stock exchanges, though they vary greatly in scope and modes of operation. Although private entities, stock exchanges play a potentially strategic role in economic development as vehicles for capitalizing a wide range of enterprises, both public and private. The extent to which they do so depends, nevertheless, on the transparency

\footnotetext{
${ }^{1}$ These institutions occupy different domains and interact with their respective environments in different ways. Nonetheless, all five institutions play potentially important roles in national development. The goal is to understand the determinants of organizational success and failure, including those related to the nature of the mission each institution is charged to fulfil.
} 
of their operations and on the trust that companies and investors have in the inviolability of their rules (Sabel, 1994; Hollingsworth, 2002).

Tax authorities underwrite the capacity of states to foster economic development and social equity. Traditionally, Latin American states have financed themselves through taxes on commodity exports and manufactured imports, external indebtedness and inflation (Velasco, 2008; Wormald and Cardenas, 2008). The imperatives of global trade and finance have progressively reduced each of these avenues, forcing states to turn inwards towards value-added and income taxes. This has raised the profile of tax authorities and added urgency to reforming them. The extent to which such efforts have been successful in the face of generalized resistance to fiscal exactions remains uncertain and was one of the specific questions posed by the study.

Public Health Services are redistributive institutions that seek to compensate for economic disparities by making a basic good available to all the citizenry. In this pursuit, these services must balance scarcity of resources with a rising demand. The long-term mission of this institution entails a notable dilemma: past successes in reducing infant mortality and preventing epidemics translate into increasing pressure on scarce resources by a larger, and longer-living population (Cereceda et al., 2008). The field studies focused on how managers and health providers seek to cope with these tensions and fulfil (or not) the redistributive goals for which the institution was created.

Postal Systems are a traditional public service, much maligned in many countries for their inefficiency and slowness, but still vital for communication and the conduct of trade. The unreliability of the mail systems in many Latin countries has led governments to partially privatize the service, allowing private operators to compete head on with the public agency (Diaz, 2006; Lujan Ponce, 2008). This decision has challenged the very existence of the institution. Our study targeted the postal system as a 'strategic site' (Merton, 1987) in order to examine how past operational practices have led to its present crisis and the various ways in which the system is seeking ways to 're-invent' itself.

Civil aviation authorities were selected because of their vital role in enabling international communication and trade. Airports, especially in the capital city, are the face of the nation and, as such, are objects of great attention for governments and economic elites alike. Airport construction and operation and the regulation of civil aviation are 'modern' pursuits that require considerable technical expertise. This led us to the initial expectation that civil aviation authorities would represent what Evans (1989) called 'islands of excellence' within the government 
apparatus since, otherwise, the country would be decertified by international agencies and vital communications with the outside world would be disrupted.

Of the five institutions targeted for study, the stock exchange and the tax authority can be categorized as mostly economic agencies, although tax collection can also have an important redistributive function. Public health services and the postal system are mostly socially oriented agencies, the first because of its intrinsic welfare mission and the second because of its mandate to link all regions of the country and make its services available to everyone. Civil aeronautics falls in-between as a mostly technical organization entrusted with a strategic mission.

\subsection{Data collection and analysis}

The units of analysis are complex organizations, each governed by its respective institutional blueprint. Their study required an intensive effort of data collection. This task was entrusted to experienced teams of investigators in each country, with individual members charged with a particular institution studied with a common methodology. Data collection included the following: (a) compilation of the legal rules defining the mission and governing the activities of the organization; (b) compilation of internal reports and evaluations; (c) compilation of external academic and journalistic reports; (d) interviews with institutional personnel at the levels of top management, mid-level management and technical personnel; (e) interviews with expert informants; (f) interviews with strategic users of institutional services (i.e. commercial airlines, pension funds investing in the stock market, mass mail marketers, etc.) For each institution and each country, 15 to 30 detailed interviews were conducted, divided about equally between internal personnel at different levels and external informants.

By combining these different forms of data collection, investigators were able to arrive at an authoritative assessment of all the dimensions of interest. These took the form of both discursive reports and a scoring of the organization on a list of characteristics, to be described next. The final sample comprises 23 institutional studies. (There is no stock exchange in the Dominican Republic and, due to financial and time limitations, the Argentine public health service was not included.) Table 1 presents a list of the sampled institutions, their titles, electronic addresses and dates of formal establishment.

Analysing this large sample to answer the questions posed previously requires more than simple intuition. For this purpose, we arranged scores for each institution in truth tables, as proposed by Ragin $(1987,2000)$. This method allows the identification of basic patterns and differences that may be obscured in discursive reports. Once such patterns are identified, it is possible to return to the reports for illustrative and supportive evidence. In addition, organizational scores can be 
Table 1 Institutions included in the comparative study, 2006-2008

\begin{tabular}{|c|c|c|c|}
\hline $\begin{array}{l}\text { Country/ } \\
\text { Institution }\end{array}$ & Name & Website & $\begin{array}{l}\text { Formal/Legal } \\
\text { establishment }\end{array}$ \\
\hline \multicolumn{4}{|l|}{ Argentina } \\
\hline Postal service & $\begin{array}{l}\text { Correo Oficial de la Repúb- } \\
\text { lica Argentina (CORASA) }\end{array}$ & $\begin{array}{l}\text { www. } \\
\text { correoargentino. } \\
\text { com.ar }\end{array}$ & 2004 \\
\hline Civil aviation & $\begin{array}{l}\text { Comando de Regiones } \\
\text { Aéreas (disbanded)/ } \\
\text { Administración Nacional } \\
\text { de Aviación Civil }\end{array}$ & www.anac.gov.ar & $1966 / 2007$ \\
\hline $\begin{array}{l}\text { Stock } \\
\text { exchange }\end{array}$ & $\begin{array}{l}\text { Bolsa de Comercio de } \\
\text { Buenos Aires (BCBA) }\end{array}$ & $\begin{array}{l}\text { www.bcba.sba.com. } \\
\text { ar }\end{array}$ & 1969 \\
\hline Tax agency & $\begin{array}{l}\text { Dirección General Impositiva } \\
\text { (DGI) }\end{array}$ & www.afip.gob.ar & 1996 \\
\hline \multicolumn{4}{|c|}{ 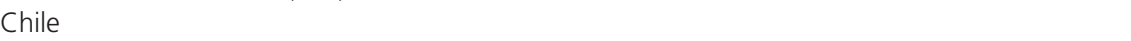 } \\
\hline Postal service & $\begin{array}{l}\text { Empresa de Correos de Chile } \\
\text { (CorreosChile) }\end{array}$ & www.correoschile.cl & 1981 \\
\hline Civil aviation & $\begin{array}{l}\text { Dirección General de Aero- } \\
\text { náutica Civil (DGAC) }\end{array}$ & www.dgac.cl & 1968 \\
\hline $\begin{array}{l}\text { Stock } \\
\text { exchange }\end{array}$ & $\begin{array}{l}\text { Bolsa de Comercio de San- } \\
\text { tiago de Chile (BCSC) }\end{array}$ & $\begin{array}{l}\text { www. } \\
\text { bolsadesantiago. } \\
\text { com }\end{array}$ & 1893 \\
\hline Health system & $\begin{array}{c}\text { Complejo Asistencial Barros } \\
\text { Luco/Ministerio de Salud }\end{array}$ & redsalud.gov.cl & 2003 \\
\hline Tax agency & $\begin{array}{l}\text { Servicio de Impuestos Inter- } \\
\text { nos (SII) }\end{array}$ & www.sii.cl & 1980 \\
\hline \multicolumn{4}{|l|}{ Colombia } \\
\hline Postal service & $\begin{array}{l}\text { La Administración Postal } \\
\text { Nacional (Adpostal) }\end{array}$ & Disbanded & 1992 \\
\hline Civil aviation & Aeronáutica Civil (Aerocivil) & $\begin{array}{l}\text { www.aerocivil.gov. } \\
\text { co }\end{array}$ & 1992 \\
\hline $\begin{array}{l}\text { Stock } \\
\text { exchange }\end{array}$ & $\begin{array}{l}\text { Bolsa de Valores de Colom- } \\
\text { bia (BVC) }\end{array}$ & www.bvc.com.co & 2001 \\
\hline Health care & $\begin{array}{l}\text { Clínica San Pedro Claver/ } \\
\text { Empresas Promotoras de } \\
\text { Salud (EPS) }\end{array}$ & Disbanded & $1962 / 2003$ \\
\hline Tax agency & $\begin{array}{l}\text { Dirección de Impuestos y } \\
\text { Aduanas Nacionales } \\
\text { (DIAN) }\end{array}$ & www.dian.gov.co & 1993 \\
\hline \multicolumn{4}{|c|}{ Dominican Republic } \\
\hline Postal service & $\begin{array}{l}\text { Instituto Postal Dominicano } \\
\text { (INPOSDOM) }\end{array}$ & $\begin{array}{l}\text { www.inposdom.gob. } \\
\text { do }\end{array}$ & 1985 \\
\hline Civil aviation & $\begin{array}{l}\text { Instituto Dominicano de } \\
\text { Aviación Civil (IDAC) }\end{array}$ & www.idac.gov.do & 2006 \\
\hline Health system & Sistema Público de Salud & www.sespas.gov.do & 2001 \\
\hline Tax agency & $\begin{array}{l}\text { Dirección General de } \\
\text { Impuestos Internos (DGII) }\end{array}$ & www.dgii.gov.do & 2006 \\
\hline
\end{tabular}


Table 1 Continued

\begin{tabular}{|c|c|c|c|}
\hline $\begin{array}{l}\text { Country/ } \\
\text { Institution }\end{array}$ & Name & Website & $\begin{array}{l}\text { Formal/Legal } \\
\text { establishment }\end{array}$ \\
\hline \multicolumn{4}{|l|}{ Mexico } \\
\hline Postal service & $\begin{array}{l}\text { Servicio Postal Mexicano } \\
\quad \text { (Sepomex) }\end{array}$ & $\begin{array}{l}\text { www.sepomex.gob. } \\
\text { mx }\end{array}$ & 1986 \\
\hline Civil aviation & $\begin{array}{l}\text { Dirección General de Aero- } \\
\quad \text { náutica Civil (DGAC) }\end{array}$ & dgac.sct.gob.mx & 1956 \\
\hline $\begin{array}{l}\text { Stock } \\
\text { exchange }\end{array}$ & $\begin{array}{l}\text { Bolsa Mexicana de Valores } \\
\text { (BMV) }\end{array}$ & www.bmv.com.mx & 1975 \\
\hline Health system & $\begin{array}{l}\text { Hospital General Manuel } \\
\text { Gea González (HGMGG) }\end{array}$ & $\begin{array}{l}\text { www.hospitalgea. } \\
\text { salud.gob.mx }\end{array}$ & 1972 \\
\hline Tax agency & $\begin{array}{l}\text { Servicio de Administración } \\
\text { Tributaria (SAT) }\end{array}$ & sat.gob.mx & 1995 \\
\hline
\end{tabular}

subjected to systematic analysis employing qualitative comparative analysis (QCA). QCA uses Boolean algebra to identify causal determinants that are sufficient, necessary or neither for a particular outcome to exist. The method does justice to the combinatorial logic of social causation by identifying interaction effects among determinants, so that factors that may not produce the outcome by themselves, do so in combination with others (Ragin, 1987; Vaisey, 2009).

QCA methodology requires reliable indicators of both potential causal factors and effects. For this, we rely on the experience and investigative effort by each research team. While the institutional scores do contain a 'reputational' element, its validity is checked against the evaluations of a plurality of informants and by months of observation of the actual performance of each organization. Institutional scores were assigned independently by each investigator.

\subsection{Hypotheses}

From the research literature, we draw six factors that have been associated with bureaucratic quality and developmental performance in the past. The work of Rodrik et al. (2002) and of Nee and Opper (2009) prove particularly useful in this regard. The identified factors are not long-term historical forces, such as those examined by Acemoglu et al. (2001), but more proximate characteristics of institutional quality. For the purposes of the study, 'development' was defined as a composite of economic growth, greater social equity and democratic rights (Portes, 1997; Sen, 1999). More broadly, the concept can be equated with sustained improvements in the well-being of a nation's population.

Investigators were asked to evaluate the extent to which the organization studied contributed to this goal in its respective institutional sphere. One cannot expect the postal system to improve university education or the civil aeronautics 
agency to increase agricultural productivity. Each agency would be evaluated as 'developmental' to the extent that it fulfils its mission and, in addition, seeks to improve the quality of its services and extend them to all sectors of the nation. Factors hypothesized to lead to this outcome can be categorized as those internal to the organization and those affecting it from the outside. The theoretical work of Evans $(1979,1995,2004 b)$ identifies two internal conditions necessary for developmental institutions:

(I) Meritocratic recruitment and promotion.

(II) Immunity from bribe-taking, and 'capture' by special interests.

The recent research literature on actual organizational experiences in Asia and Latin America (Gereffi, 1989; Kochanowicz, 1994; Nee, 2000; MacLeod, 2004) identifies a third key internal determinant:

(III) Absence of entrenched 'islands of power' capable of subverting institutional rules to their own ends.

Recruitment and promotion based on family connections or other personalistic ties is the opposite of Condition I. A poorly paid or otherwise demoralized bureaucracy 'for sale' to outside bidders is the alternative to Condition II. Powerful managerial cliques and self-seeking union bureaucracies negate Condition III. All three internal conditions are related, but they are not the same: initial meritocratic recruitment and promotion may be subsequently corrupted by special interests; entrenched islands of power may be immune to outside corruption to the extent that they can channel significant internal resources to their own ends, thus subverting the original institutional goals (MacLeod, 2004).

Evans's work can again be drawn upon as the source of the first external determinant:

(IV) Proactivity or the ability of the organization to involve itself with clients, users and other relevant actors in its institutional environment.

Evans (1995) labels this condition 'embeddedness'. Here, we will use 'proactivity' given the prior association of 'embeddedness' with the theoretical work of Granovetter (1985), which has an important but altogether different meaning. The final external conditions are derived from the work of John Meyer and his associates (Meyer and Hannan, 1979; Meyer and Boli, 1997) on global diffusion of institutional forms and those of Cardoso and Faletto (1979); Zeitlin (1984); O'Donnell (1994); and Portes and Hoffman (2003), on Latin American class structures and their role in perpetuating socio-economic inequality:

(V) Technological flexibility and openness to external innovation. 
(VI) Countervailing power, either by the organization itself or its external allies, to prevent control by particularistic interests in the dominant classes.

Condition IV is negated by inward-looking institutions that seek to protect their own interests and internal cohesiveness, turning a deaf ear to clients, users and potential outside opportunities. The opposite of Condition $\mathrm{V}$ is institutional rigidity with entrenched traditions - 'the way things have always been done'prevailing over external opportunities for innovation.

Reflecting the hierarchies of power portrayed in Figure 1, an institution, no matter how well-designed, that lacks backers and sponsors among top officialdom or among influential elites is likely to fall prey to dominant class interests or to find a 'class wall' frustrating its mission. The experiences of numerous failed agrarian reform programmes in Latin America and the well-studied demise of the early Mexican privatization programme confronted with unified class resistance (MacLeod, 2004) provide object lessons of the role of power in subverting the best laid-out institutional plans.

Research teams used these hypotheses as guides to organize their respective studies and, in addition, were asked to rank each individual organization on each predictor in each of the scales described above. These evaluations and the accompanying narratives form the database for the analysis presented next.

\section{Results}

\subsection{General trends}

Table 2 presents a Truth Table drawn from the dichotomous evaluations produced by the 23 institutional studies. Prior to subjecting these data to algebraic manipulation, it is possible to identify several important trends. These have to do both with differences among institutions and differences among countries. The table breaks down outcomes into two components. First, an initial assessment of whether the organization meets the institutional goals for which it was created, as reflected in the relevant enabling law or formal regulation. Second, a summary assessment of whether it is developmental in its institutional sphere.

A perusal of scores in the table indicates a marked divide between organizations and agencies whose prime mission is economic and those that focus on services to the general population. Consistently, stock exchanges and, especially, tax authorities rank high, while zeros in the binary scale tend to cluster in the post office, the national health service and, to a lesser extent, civil aeronautics.

The crisp binary logic of Boolean algebra commends itself for clarity, but imposes strict limits on reality and on researchers' evaluations. To address this 
Table 2 Truth Table of institutional adequacy and contributions to national development

\begin{tabular}{|c|c|c|c|c|c|c|c|c|}
\hline \multirow[b]{2}{*}{$\begin{array}{l}\text { Country/ } \\
\text { Institution }\end{array}$} & \multirow[b]{2}{*}{ A. Meritocracy } & \multicolumn{3}{|l|}{ Determinants $^{1}$} & \multirow[b]{2}{*}{$\begin{array}{l}\text { E. Technological } \\
\text { flexibility }\end{array}$} & \multirow[b]{2}{*}{$\begin{array}{l}\text { F. External } \\
\text { allies }\end{array}$} & \multicolumn{2}{|l|}{ Results } \\
\hline & & $\begin{array}{l}\text { B. Immunity } \\
\text { to corruption }\end{array}$ & $\begin{array}{l}\text { C. No } \\
\text { 'islands } \\
\text { of power' }\end{array}$ & D. Proactivity & & & $\begin{array}{l}\text { I. Institutional } \\
\text { adequacy }\end{array}$ & $\begin{array}{l}\text { II.Contribution } \\
\text { to development }\end{array}$ \\
\hline \multicolumn{9}{|l|}{ Chile } \\
\hline Postal service & 1 & 1 & 1 & 1 & 0 & 0 & 1 & 1 \\
\hline Civil aviation & 1 & 1 & 1 & 1 & 1 & 0 & 1 & 1 \\
\hline $\begin{array}{l}\text { Stock } \\
\text { exchange }\end{array}$ & 1 & 1 & 1 & 1 & 1 & 1 & 1 & 1 \\
\hline $\begin{array}{l}\text { Health care } \\
\text { system }\end{array}$ & 1 & 1 & 1 & 1 & 1 & 0 & 1 & 1 \\
\hline Tax agency & 1 & 1 & 0 & 1 & 1 & 1 & 1 & 1 \\
\hline \multicolumn{9}{|l|}{ Colombia } \\
\hline Postal service & 0 & 0 & 0 & 0 & 0 & 0 & 0 & 0 \\
\hline Civil aviation & 1 & 1 & 1 & 0 & 1 & 0 & 1 & 0 \\
\hline $\begin{array}{l}\text { Stock } \\
\text { exchange }\end{array}$ & 1 & 1 & 1 & 0 & 1 & 1 & 1 & 0 \\
\hline $\begin{array}{l}\text { Health care } \\
\text { system }\end{array}$ & 0 & 0 & 0 & 0 & 1 & 0 & 0 & 0 \\
\hline Tax agency & 0 & 0 & 0 & 1 & 1 & 0 & 0 & 0 \\
\hline \multicolumn{9}{|l|}{ Mexico } \\
\hline Postal service & 0 & 0 & 0 & 1 & 0 & 1 & 0 & 1 \\
\hline Civil aviation & 1 & 1 & 1 & 0 & 1 & 0 & 1 & 0 \\
\hline $\begin{array}{l}\text { Stock } \\
\text { exchange }\end{array}$ & 1 & 1 & 1 & 1 & 1 & 1 & 1 & 1 \\
\hline $\begin{array}{l}\text { Health care } \\
\text { system }\end{array}$ & 1 & 1 & 1 & 1 & 1 & 1 & 1 & 1 \\
\hline Tax agency & 0 & 1 & 1 & 1 & 1 & 1 & 1 & 1 \\
\hline
\end{tabular}




\begin{tabular}{|c|c|c|c|c|c|c|c|c|}
\hline \multicolumn{9}{|l|}{ Argentina } \\
\hline Postal service & 0 & 0 & 0 & 1 & 1 & 1 & 1 & 0 \\
\hline Civil aviation & 0 & 0 & 0 & 0 & 0 & 0 & 0 & 0 \\
\hline $\begin{array}{l}\text { Stock } \\
\text { exchange }\end{array}$ & 0 & 1 & 0 & 1 & 1 & 1 & 1 & 0 \\
\hline Tax agency & 1 & 0 & 0 & 1 & 1 & 1 & 1 & 1 \\
\hline \multicolumn{9}{|c|}{ Dominican Republic } \\
\hline Postal service & 0 & 0 & 0 & 0 & 0 & 0 & 0 & 0 \\
\hline Civil aviation & 1 & 1 & 1 & 1 & 1 & 1 & 1 & 1 \\
\hline $\begin{array}{l}\text { Health care } \\
\text { system }\end{array}$ & 0 & 0 & 0 & 0 & 0 & 0 & 0 & 0 \\
\hline Tax agency & 0 & 0 & 1 & 1 & 1 & 1 & 1 & 1 \\
\hline
\end{tabular}

Notes: 1, presence; 0 , absence. 
problem, Ragin (2004) introduced an alternative methodology based on 'fuzzyset' algebra that allows the analysis of cases coded along a conceptual continuum. Accordingly, each organization studied received a second code for each hypothesized determinant and each outcome in a 1-to-5 scale. Table 3 presents the results of this exercise. The conceptual meaning of each score in the scale is specified at the bottom of the table.

The trend of scores in this table is essentially the same as that observed in the binary rankings. A second trend in the data is the marked differences in institutional rankings among the five countries included in the study. A reading of individual reports confirms these trends and clarifies their historical origins. We will return to these results in the final sections after we finish examining the two Truth Tables as regards to the characteristics defining a truly developmental institution.

\subsection{Determinants of institutional quality}

For this purpose, we make use of the QCA methodology in its two variants — crisp sets using Boolean algebra and fuzzy sets, using the alternative algebraic method developed by L. Zadeh (Ragin, 2000, pp. 171-180). Although the outcomes in Tables 2 and 3 are broken down into two sub-components, we focus the analysis on the final one-namely the extent to which the organization can be defined as 'developmental'. Following convention, the six hypothesized determinants described previously are identified by capital letters-A to F (Ragin, 1987).

Crisp-set analysis. According to the data in Table 2, a developmental institution (DI) is brought about by the following causal combinations (frequencies in parentheses):

$$
\begin{aligned}
\mathrm{DI}= & \mathrm{ABCDEF}(4)+\mathrm{ABCDE}(2)+\mathrm{ABCD}(1)+\operatorname{ABDEF}(1)+\operatorname{CDEF}(1) \\
& +\operatorname{ADEF}(1)+\mathrm{BCDEF}+\mathrm{DF}(1) .
\end{aligned}
$$

These combinations are known as primitive terms; before proceeding to minimize them, three points should be noted: first, in Boolean algebra, the absence of a cause (denoted by lower-case letters) has the same theoretical status as its presence. We omit lower-case letters from equation (1) for clarity and because no theory exists that predicts that absence of any of these predictors would lead to a positive result. Complete algebraic expressions for each primitive term can be reached by simply adding lower-case letters for missing predictors to any four- or five-term in equation (1).

Second, equations listed in Table 2 are a subset of all possible logical combinations of the six predictors and the outcome. The number of such combinations is $2^{k}$, for $k$ number of determinants, yielding 64 possible combinations in our case. 
Table 3 Truth table of scores assigned to institutions in hypothesized predictors and outcomes

\begin{tabular}{|c|c|c|c|c|c|c|c|c|}
\hline \multirow[b]{2}{*}{ Country/Institution } & \multicolumn{6}{|l|}{ Determinants $^{1}$} & \multicolumn{2}{|l|}{ Results } \\
\hline & A. Meritocracy & $\begin{array}{l}\text { B. Immunity to } \\
\text { corruption }\end{array}$ & $\begin{array}{l}\text { C. No 'islands } \\
\text { of power' }\end{array}$ & D. Proactivity & $\begin{array}{l}\text { E. Technological } \\
\text { flexibility }\end{array}$ & F. External allies & $\begin{array}{l}01 \text { Institutional } \\
\text { adequacy }\end{array}$ & $\begin{array}{l}02 \text { Contribution } \\
\text { to development }\end{array}$ \\
\hline \multicolumn{9}{|l|}{ Chile } \\
\hline Postal service & 4 & 3 & 4 & 5 & 3 & 2 & 4 & 5 \\
\hline Civil aviation & 3.5 & 4 & 3 & 4 & 5 & 3 & 5 & 4 \\
\hline Stock exchange & 4 & 4 & 3.5 & 5 & 4 & 5 & 4 & 4 \\
\hline Health care system & 3.5 & 3.5 & 2.5 & 3.5 & 2 & 1 & 4 & 3.5 \\
\hline Tax agency & 4 & 4 & 2.5 & 4 & 5 & 4 & 3.5 & 4 \\
\hline \multicolumn{9}{|l|}{ Colombia } \\
\hline Postal service & 2 & 2 & 3 & 2 & 2.5 & 1 & 1 & 1 \\
\hline Civil aviation & 4 & 3 & 3.5 & 2 & 5 & 2.5 & 4 & 3 \\
\hline Stock exchange & 4 & 3.5 & 3.5 & 2 & 3.5 & 4 & 4 & 2 \\
\hline Health care system & 2 & 2 & 3 & 2 & 4 & 3 & 1 & 1 \\
\hline Tax agency & 2 & 1 & 2 & 4 & 4 & 2 & 2 & 2 \\
\hline \multicolumn{9}{|l|}{ México } \\
\hline Postal service & 1 & 2 & 1 & 3.5 & 1 & 3.5 & 1 & 3.5 \\
\hline Civil aviation & 4 & 3.5 & 4 & 1.5 & 3.5 & 1.5 & 4 & 2.5 \\
\hline Stock exchange & 4 & 3.5 & 3.5 & 3.5 & 5 & 3.5 & 4 & 4 \\
\hline Health care system & 4 & 3 & 4 & 4 & 4 & 3 & 4 & 4 \\
\hline Tax agency & 2 & 4 & 5 & 4 & 5 & 3 & 4 & 4 \\
\hline \multicolumn{9}{|l|}{ Argentina } \\
\hline Postal service & 2 & 1 & 2 & 3 & 4 & 4 & 3 & 2 \\
\hline Civil aviation & 2 & 2 & 2 & 1 & 2 & 1 & 2 & 1 \\
\hline Stock exchange & 3 & 3 & 2 & 4 & 3 & 3 & 4 & 2 \\
\hline Tax agency & 4 & 1 & 3 & 4 & 5 & 5 & 4 & 4 \\
\hline
\end{tabular}


Table 3 Continued

\begin{tabular}{|c|c|c|c|c|c|c|c|c|}
\hline \multirow[b]{2}{*}{ Country/Institution } & \multicolumn{6}{|l|}{ Determinants $^{1}$} & \multicolumn{2}{|l|}{ Results } \\
\hline & A. Meritocracy & $\begin{array}{l}\text { B. Immunity to } \\
\text { corruption }\end{array}$ & $\begin{array}{l}\text { C. No 'islands } \\
\text { of power' }\end{array}$ & D. Proactivity & $\begin{array}{l}\text { E. Technological } \\
\text { flexibility }\end{array}$ & F. External allies & $\begin{array}{l}01 \text { Institutional } \\
\text { adequacy }\end{array}$ & $\begin{array}{l}02 \text { Contribution } \\
\text { to development }\end{array}$ \\
\hline \multicolumn{9}{|l|}{ Dominican Republic } \\
\hline Postal service & 1 & 1 & 2 & 2 & 2 & 2 & 2 & 2 \\
\hline Civil aviation & 3.5 & 3.5 & 3.5 & 5 & 3.5 & 4 & 4 & 4 \\
\hline Health care system & 1 & 2 & 1 & 2 & 2 & 1 & 1 & 2.5 \\
\hline Tax agency & 3 & 3 & 4 & 4 & 5 & 4 & 4 & 4 \\
\hline
\end{tabular}

Notes: 1 , entirely outside the conceptual set defined by the variable; 2 , more outside than inside; 3, neither; 4 , more inside than outside; 5 , entirely inside. 
The non-existent 41 logical expressions can be disregarded or can be treated as 'counterfactuals' by assuming that, had they existed, they would have led to a positive or, alternatively, a negative outcome (Ragin, 2004). The most conservative approach is to assume that non-existent combinations would not lead to the outcome of interest and this is the option adopted in the following analysis.

Finally, with a sample of institutions of this size, several solutions are possible. The ultimate decision is between 'complexity' and 'parsimony' (Ragin, 2004). Parsimonious solutions are attractive because of their simplicity, since they include only those elements common to all primitive terms. That very simplicity may make them less appealing because they do not capture the more complex combinations that actually produce the relevant outcome. In the end, the preferred solution comes about as a result of a dialogue between the empirical results and plausible theoretical expectations.

Reduction of the primitive terms in equation (1) faces one anomalous finding. This is linked to the Mexican postal service, which received a score of 0 in institutional adequacy (Table 2), but was, nevertheless, evaluated as a developmental institution. It is implausible that a state agency could simultaneously fail to meet the goals for which it was created and be capable of furthering the nation's progress. This anomaly led us to re-read the rationale for these evaluations. The institutional report for SEPOMEX, the Mexican postal service, finds that it was riddled with corruption and on the verge of extinction. Postal workers even use the term 'milking the mails' to refer to the common practice of opening letters in search of cheques, money orders or cash (Lujan Ponce, 2008).

SEPOMEX was only saved, at least temporarily, by the direct intervention of the president of the republic who appointed a new director and provided the service with a significant budgetary increase. Still, it is an open question whether the agency will survive. The positive evaluation on development given to this organization, despite its sorry state, is due to its past rather than its present. The investigator in charge argued that, historically, the post office fulfilled an important integrative function by linking all regions of the country and representing the state in its most remote corners (Lujan Ponce, 2008). While this is plausible, history is no substitute for present performance, as an organization near collapse cannot make a contribution to the nation's progress. SEPOMEX accounts for the last causal expression in equation (1): DF. Its removal allows for minimization of the other primitive terms into a parsimonious solution which covers $100 \%$ of other primitive terms with a consistency of $1.00^{2}$ :

$$
\mathrm{DI}=\mathrm{D}(\mathrm{A}+\mathrm{C}) \text {. }
$$

${ }^{2}$ Consistency is defined as the degree to which one set is contained into another $\left(x_{i} \leq y i\right)=$ $\sum\left(\min x_{i} y_{i}\right) / \sum\left(x_{i}\right)$. By counting the portion of $x_{i}$ values that violate this criterion in the 
The causal expression in equation (2) highlights the key role of proactivity (D) in making an institution capable of yielding significant developmental outcomes. In agreement with Evans's $(1979,1995)$ theory, it is not enough for an institution to be meritocratic or immune to corruption if it is inward-oriented. To further development in its sphere of action, it must leave its protected turf and engage with key actors in society, organizing them and creating incentives to achieve various strategic goals.

An alternative solution that includes SEPOMEX, despite the problems noted, yields:

$$
\mathrm{DI}=\mathrm{ABCD}+\mathrm{DF}(\mathrm{A}+\mathrm{C})
$$

or, by algebraic manipulation:

$$
\mathrm{D}(\mathrm{ABC}+\mathrm{AF}+\mathrm{CF})
$$

$\mathrm{D}$ is identified again as the necessary condition for a developmental institution, a role highlighted in equation (4). Hence, inclusion of the anomalous case produces a more unwieldy solution, but does not detract from the original conclusion: in every case, proactivity is the sole necessary condition.

Fuzzy-set analysis. As noted previously, fuzzy-set methods were introduced to overcome the limitations of binary evaluations. QCA methodology also permits the identification of necessity and sufficiency based on these scores.

Necessary conditions are always present when the outcome is positive, but they may be present without the outcome materializing. Fuzzy sets translate this criterion into the expectation that scores in the predictor will be higher than or equal to that in the outcome. Intuitively, membership in the set defined by the effect is a subset of that defined by membership in the cause (Ragin, 2000, Ch. 8). Necessary conditions thus create a 'ceiling' for the expected effect. Sufficient conditions always lead to the effect but the latter may also occur in their absence, due to other factors. The translation into fuzzy sets is that scores in the set defined by the predictor be equal or lower than scores in the outcome. In effect, sufficient conditions create a 'floor' for the outcome, by assuming that membership in that set is a superset of that defined by the outcome. The logic of necessary and sufficient conditions is summarized in Figure 2.

Table 4 presents the relevant data for the analysis of necessity and sufficiency. A perusal of the results indicates that no single factor fulfils the requirements for a necessary condition but that, similar to crisp-set findings, D comes closest to fulfilling the criteria. If cases where D scores are fractionally inferior (0.5) in the outcome are included, this predictor would cover $91.3 \%$ of the cases. Second in the definition 
Requirement

Cause $\geq$ Effect $^{1} \quad$ Effect $\geq$ Cause $^{2}$

Necessary $\quad x \quad 0$

Determinant

Sufficient $\quad 0 \quad x$

1. If the cause is present, the effect may or may not be present. The effect is a
subset of the cause.
2. If the effect is present, the cause is also present, although other causes can
also produce the effect. The cause is a subset of the effect.

Figure 2 Necessary and sufficient conditions in fuzzy-set algebra.

Table 4 Fuzzy-set sufficient and necessary conditions for a developmental institution

\begin{tabular}{|c|c|c|c|}
\hline & Determinants & $\begin{array}{l}\text { Necessity } \\
\text { (cause } \geq \text { effect), \% }\end{array}$ & $\begin{array}{l}\text { Sufficiency } \\
\text { (effect } \geq \text { cause), \% }\end{array}$ \\
\hline Internal & $\left\{\begin{array}{l}\text { A. Meritocracy } \\
\text { B. Immunity to corruption } \\
\text { C. No 'islands of power' }\end{array}\right.$ & $\begin{array}{l}65.2 \\
52.2 \\
56.5\end{array}$ & $\begin{array}{l}69.6 \\
73.9 \\
69.6\end{array}$ \\
\hline External & $\begin{array}{l}\left\{\begin{array}{l}\text { D. Proactivity } \\
\text { E. Openness to technological } \\
\text { innovations } \\
\text { F. External allies }\end{array}\right. \\
\text { Complex Solutions } \\
D+E \\
D(A+C)\end{array}$ & $\begin{array}{l}82.6 \\
78.3 \\
60.9 \\
100.0\end{array}$ & $\begin{array}{l}69.6 \\
34.8 \\
73.9\end{array}$ \\
\hline
\end{tabular}

Notes: $N=23$ institutions in five countries.

of necessity is technological flexibility (E). Joining the two predictors with a plus sign ('or') and disregarding fractional discrepancies, coverage reaches $100 \%$ of the cases. Proactivity is easily the strongest predictor accounting, by itself, for the bulk of sample coverage. Based on this difference, we conclude that D is the 'usually necessary' condition for the emergence of a developmental institution.

The pattern of results in Table 4 shows that no individual factor comes close to the criteria of sufficiency, each registering many exceptions. We are, hence, forced to consider more complex solutions. A solution suggested by the algorithm of the fuzzy-set program is:

$$
\mathrm{DI}=(\mathrm{AD}+\mathrm{BD})(\mathrm{E}+\mathrm{F}) \text { or, by algebraic manipulation: } \mathrm{D}(\mathrm{AEF}+\mathrm{BEF}) .
$$


While this causal expression again highlights the central role of $\mathrm{D}$, it is rather unwieldy as it uses almost all predictors. In addition, solution coverage is only $71.1 \%$ of the sample. A more parsimonious alternative would be:

$$
\mathrm{DI}=\mathrm{D}(\mathrm{A}+\mathrm{C}) \text {. }
$$

This increases coverage to $83.2 \%$ with a high level of consistency $(92.9 \%)$. Plotting equations (5) and (6) in Figures 3 and 4 yields similar results. In both instances, an upper-left triangle concentration of cases is observable, with most falling on or near the diagonal. This is an indicator of a satisfactory causal solution for sufficient conditions (Ragin, 2000, 2008). Equation (6) is, of course, identical to results produced by the crisp-set analysis, once the anomalous case of SEPOMEX was set aside. For this reason, and in the interest of parsimony, we adopt it as the best solution emerging from the analysis.

A final alternative solution is arrived at by inspection of scores in Table 3 and by taking advantage of the combinatorial rule of fuzzy-set algebra that equates membership in a complex set with the lowest score of its components. Using this rule, we may join the terms in equation (6) into the expression:

$$
\mathrm{DI}=\mathrm{ACD}
$$

that achieves coverage of $91.3 \%$ or 21 out of 23 cases without the need to adjust for fractional discrepancies. The two exceptions are the Colombian postal service and the Colombian public health service whose developmental profiles were so low as to prevent fulfilment of the minimum criteria for sufficiency.

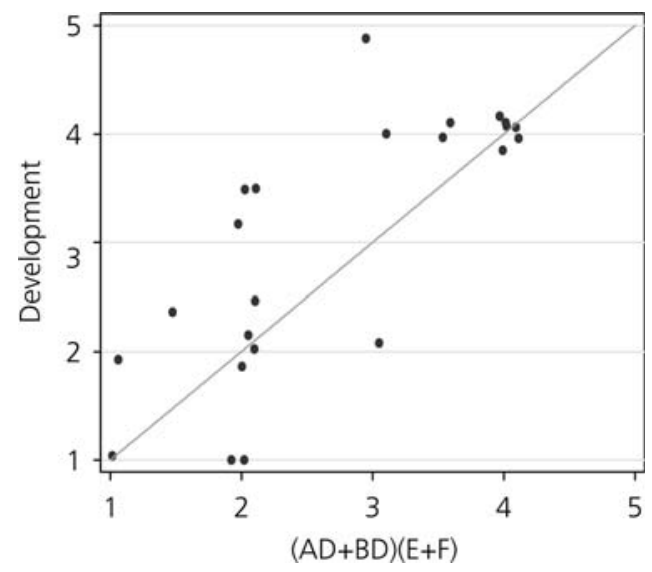

Figure 3 Organizational membership in the causal complex ' $(A D+B D)(E+F)^{\prime}$ and contributions to development. 


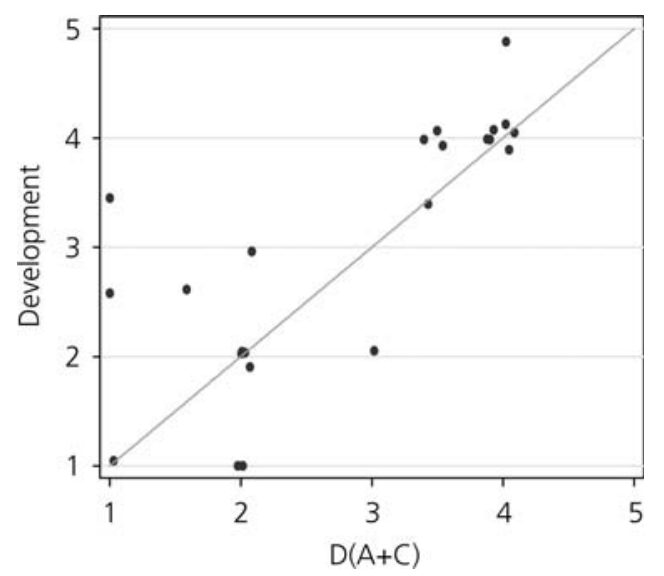

Figure 4 Organizational membership in the causal complex ' $D(A+C)$ ' and contributions to development.

Whether one adopts equation (6) or (7) as a sufficient condition, the individual components are the same. Theoretically, these causal patterns indicated that proactivity is necessary, but not sufficient for a developmental institution and that it must be buttressed by one or more internal dimensions. The combination of just one dimension of internal quality with proactivity is sufficient, in most cases, to bring about the outcome. This conclusion is similar and actually simplifies that produced by the previous binary analysis.

In sum, results based on scores in Tables 2 and 3 do not differ markedly and actually support each other. Adjudicating between alternative solutions on the basis of parsimony and prior theoretical expectations leads us to conclude that organizations will not be considered developmental by fulfilling the familiar internal criteria of meritocracy, immunity to corruption and absence of entrenched interests. Such 'Weberian' organizations will not spur developmental goals if they simply protect their turf; they must go beyond themselves to mobilize and energize their environment. No other factor appears more important than this stance in characterizing a developmental institution. Again, this result provides strong support for the hypothesis proposed by Evans, with the caveat that proactivity is not sufficient, but only necessary to bring about this outcome.

\subsection{Institutional differences}

We return now to the materials in the individual reports to clarify the historical origins of differences in the quality of institutions observed and differences in the 
quality of institutions among countries. As noted previously, stock exchanges and tax authorities appear to be the most consistently developmental. This was not always the case. Neither stock exchanges nor tax authorities have been historically strong institutions in Latin America. The first were, for the most part, 'gentlemen's clubs' that served as much a function of social networking as of rent-seeking, and where access was limited to males of the local elite (Rodriguez Garavito and Rodriguez Franco, 2008). Opportunities for profit in these exchanges were neither universal nor transparent, as they were restricted by particularistic ties. Tax authorities were dormant or corrupt agencies not given high priority by governments that financed themselves primarily from import and export tariffs plus external indebtedness (Velasco, 2008).

The rapid strengthening of both institutions across Latin America during the last three decades was linked to the Mexican default of 1982, the subsequent regional crisis and the advent of neoliberal reform inspired by the so-called Washington Consensus (Balassa et al., 1986; Williamson, 1994). Latin American governments were compelled to open up their markets and financial sectors to external actors. For stock exchanges, this meant the entry of powerful foreign players that pushed for greater transparency of transactions and impartial regulation. Not surprisingly, the old elites resisted. As authors of the Chilean Exchange (Bolsa de Santiago) study reported:

The most significant 'island of power' was formed by the traditional brokers who immediately opposed the entry of the banks.... A tension emerged between the reproduction of the traditional ethos proper of a 'gentlemen's club' and a modern perception that viewed the Exchange as a competitive business. (Wormald and Brieba, 2006, p. 44)

To the extent that global financial markets operate under modern norms of universalism and transparency, the interest of brokers in preserving the Exchange as a traditional agency could not but slow down the integration of the national market into global financial circles (Wormald and Brieba, 2006). This resistance threatened the institution with obsolescence, a fate that more modern economic actors resisted and that the state would not allow. Gradually, old elites were pushed back or out, and a new mechanism of regulation and control was put into place. By 2004, dominant players in the Santiago Exchange were either foreign banks or modern domestic firms allied with them. As shown in Table 5, only 2 traditional brokerage houses out of the 72 in existence in 1960 were still significant actors in this market.

This evolution led Latin American exchanges to improve their probity and openness to innovation, turning many into organizations capable of fulfilling their institutional blueprints. Stock exchanges in the region today copy 
Table 5 Sixteen largest brokerage houses in the Santiago Exchange, 2004

\begin{tabular}{llll}
\hline Broker & Type & $\begin{array}{c}\text { Gross income } \\
\text { (billion pesos) }\end{array}$ & $\begin{array}{l}\text { Profit rate, } \\
\text { 2003-2004, \% }\end{array}$ \\
\hline Banchile & Domestic commercial bank & 41,104 & 9.52 \\
Larrain Vial & Traditional broker & 14,404 & 4.77 \\
Bice & Domestic commercial bank & 27,038 & 4.50 \\
Consorcio & Investment group & 9,976 & 4.06 \\
BCI & Domestic commercial bank & 19,100 & 3.86 \\
Valores Security & Foreign investment bank & 31,268 & 3.48 \\
IM Trust & Foreign investment bank & 7,039 & 2.66 \\
Santander & Foreign commercial bank & 11,596 & 2.33 \\
$\quad$ Investment & & & \\
CorpBanca & Domestic commercial bank & 15,896 & 2.24 \\
Banco Estado & Domestic commercial bank & 9,059 & 1.90 \\
BBVA & Foreign commercial bank & 6,817 & 1.65 \\
Citigroup & Foreign commercial bank & 6,841 & 1.61 \\
Celfin & Domestic investment bank & 9,077 & 1.49 \\
Deutsche Bank & Foreign investment bank & 11,852 & 1.02 \\
Alfa & Investment group & 7,820 & 0.88 \\
Ureta and Bianchi & Traditional broker & 1,071 & 0.77 \\
& & & \\
\hline
\end{tabular}

Source: Wormald and Brieba, 'La Bolsa de Comercio de Santiago de Chile', Table 3.

Notes: The exchange rate in 2004 was US $\$ 1.00=$ Chilean $\$ 609$.

Wall Street and, to a lesser extent, the Bolsa of Madrid and monitor each other in search of the latest technological innovations. As the author of the study of the Colombian stock exchange (BVC) concludes:

The entry of the new global actors has been the most transformative force for the BVC and the Colombian financial scene. Dissatisfied with the preferential treatment granted by the Exchange to its stockholders, the new actors forced changes in corporate governance and operational functioning accompanying the Exchange's demutualization. (Rodriguez Garavito, 2006, p. 20)

Something similar happened to the tax authorities which had to be urgently revived in the wake of the region-wide financial crisis of the 1980s (Portes, 1997). The subsequent, neoliberal-inspired adjustment programmes in most countries entailed significant reduction in custom tariffs in order to open previously protected national markets to global trade. This led directly to major losses in fiscal revenue. Latin governments could not substitute import/export tariffs with foreign indebtedness since these flows had also dried up in the wake of the Mexican default and new assistance by global agencies was conditioned precisely on budget balancing, even at the cost of social unrest 
(Robinson, 1996; Roberts and Portes, 2006). Governments had recourse only to internal revenues which, in turn, required extracting fiscal resources from a most reluctant population (Guzman, 2008; Roig, 2008).

In nation after nation, the tax authority was put directly under the president of the republic who appointed its director general. The agency received operational and budgetary autonomy, and fiscal functionaries were placed on a higher pay scale than the rest of the government personnel, and were also rewarded with performance bonuses. Two important organizational innovations were introduced throughout the region: first, competent and charismatic directors were appointed, most of whom led the agency for many years; second, a Directorate of Large Contributors was established in every country. The highly unequal income distribution in these countries translates into a concentration of taxable revenues in a small minority of people and firms. In the Dominican Republic, for example, $80 \%$ of the total tax taken is accounted for by the two dozen largest firms. In Chile, only the top $18 \%$ of income earners are liable for income tax and just $6 \%$ of individuals and firms account for $92 \%$ of tax revenues (Guzman, 2008; Wormald and Cardenas, 2008).

This transformation created the conditions necessary for these agencies to meet their institutional goals. Personnel started to be recruited on qualifications and merit; bribery and corruption were significantly reduced, if not eliminated; and all agencies went digital and rapidly incorporated computer-based technology. The best of these organizations, exemplified by the Chilean Internal Revenue Service (referred to by its acronym SII), introduced technical innovations seldom seen among its peers even in the developed world:

Today, a large number of taxpayers receive their annual tax declaration prepared and sent via internet by the SII; all they have to do is examine it, sign it, and send it back. This presupposes a level of information by the agency that is ever more encompassing and reliable. (Wormald and Cardenas, 2008, p. 3)

Such developments, described in detail in the five relevant studies, account for the high scores received by most tax agencies in institutional adequacy and contribution to national development. These achievements were neither random nor the product of luck, but stemmed from a deliberate, concentrated effort by governments at the highest levels of authority. When the survival of the state was at stake, no effort was spared in producing real institutional reform.

No such luck accompanied the evolution of agencies concerned primarily with services to the general population. As shown in Tables 2 and 3, the lowest scores in determinants leading to a developmental institution correspond to public health services and, especially, the postal systems. The difficult mission of health services in seeking to extend health care to the entire population is compounded by the 
limited resources and the absence of will by the governments to make health delivery a priority comparable with tax collection. Chile, with solid external revenues from high copper prices and a string of social democratic governments, has been the most successful in this regard. The Chilean Public Health Service effectively covers the nation. A law enacted in 2004, labelled Plan Auge, guarantees free care, in public or private facilities, for the 56 most common pathologies affecting the Chilean population. A detailed study of the Barros Luco General Hospital in Santiago, which was part of the corresponding institutional report, describes a large, well-funded and well-organized facility, highly proactive towards its catchment area (Cereceda et al., 2008).

In Mexico, as well, a strong tradition of public service has compelled the state to commit significant resources to the health sector. The Mexican Institute of Social Security (IMSS) runs a complex network of hospitals and clinics covering the country. The Gea Gonzalez Hospital in Mexico City, elected for intensive study as part of this study, displays comparable characteristics to its Chilean counterpart: massive size, coverage of almost all medical specialties, technological innovation and a strong proactive stance (Gómez et al., 2008). While this institution represents a flagship for the IMSS and, therefore, its quality is likely higher than public hospitals in the interior of the country, it is still emblematic of the sustained effort of the Mexican health service to fulfil its mission.

Since the mid-1990s, the Dominican Republic has made sustained efforts to imitate these achievements. Already, $98 \%$ of pregnancies receive pre-natal health care and $97 \%$ of births take place in clinics. However, the levels of maternal and infant mortality are among the highest in the continent, indicating the poor quality of care in public health establishments (Castellanos, 2008, pp. 17-18). Most informants concurred in the significant gap that exists between governmental declarations and realities on the ground. The relevant study reaches the following conclusions:

- Meritocracy. Results support the conclusion that hiring and promotion in the Dominican public health service are at the discretion of the authorities and are poorly meritocratic.

- Probity. This feature is predominantly absent and the system is vulnerable to the pressures of outside interests in key decisions.

- Proactivity. All concurred that most decisions and changes in the public health service are defined by personalistic interests and that the general population has very little say in these decisions (Castellanos, 2008, pp. 59-60).

The most catastrophic situation is that of the Colombian health service that was disbanded in the course of our study. Heavily influenced by the free-market ideology dominant during the 1990s, the Colombian government decided to privatize its hospitals and turn them into profitable entities. This was done by the 
mid-decade passage of Law 100. The law created a double-payer system whereby state employees and those in private sector firms were covered by private insurance, while the indigent were covered by a state-financed system akin to Medicaid (this system is referred to by the Spanish acronym SISBEN) (Diaz, 2008).

This new system excluded the vast population of independent workers, those employed in informal enterprises and the unemployed. Simultaneously, it decapitalized the old Social Security Institute (ISS) which was left covering the elderly and the very ill. Newly privatized hospitals forced to fend for themselves squeezed down medical salaries and started to refuse attention to the uninsured. This led, in turn, to a wave of strike action and other protests by doctors and other medical personnel for most of the late 1990s and early 2000s. It also led to the tragic phenomenon dubbed in Colombia the 'tour of death', as uninsured and seriously ill patients were turned down, in hospital after hospital, until they died in front of one (Diaz, 2008). By 2008, the ISS and 10 large formerly public hospitals had gone bankrupt, with 79 others at the edge of collapse. Today, Colombia is painfully attempting, by fits and starts, to reverse the consequences of a catastrophic policy decision, followed by massive disinvestment in its health sector (Diaz, 2008; Rodriguez Garavito, 2010).

In all five countries, the post office is an organization in crisis, a kind of Cinderella of the governmental apparatus left at the margins by years of neglect and corruption. Although the postal service is expected to meet a key function of national integration by reaching the most remote corners of the country, this function has been perceived by governments as less urgent and less important. In one country at least, it has been common practice to turn the post office into a 'consolation prize' to the losing party in national elections (Sanchez Mariñez, 2008).

Argentina privatized the post office during the 1990s, while Colombia simply allowed it to expire, an event that happened in the course of our study (Diaz, 2006; Castellanos, 2008). Privatization did not turn out to be the promised panacea. The costs of postal services rose significantly and private companies restricted service to the most lucrative sectors of the market, abandoning small towns and isolated areas to their fate. Argentina brought the post office back into the state apparatus, and, in Chile and Mexico, last-minute efforts by the respective presidents saved the official system from extinction. In Chile, the post office appears to have surmounted its near-mortal crisis after having been put under direct state control (Cereceda, 2006). In Mexico, the fate of SEPOMEX is very much in doubt. The state of the agency prior to the recent rescue attempt is illustrated in the institutional study as follows:

In February 2008, the local press in Ciudad Juarez denounced the theft of more than ten tons of mail coming from the U.S. It was perpetrated 
by a mailman who, over ten years, opened the mail in search of checks and money orders from Mexican immigrants to their families. This event is only part of a long list of events that, if not so grave, certainly expose the insecurity suffered by users of the Mexican postal service. (Lujan Ponce, 2008, p. 22)

This brief review of institutional differences across the continent brings forth two basic points: first, the state of Latin American postal services, national health services and, to a lesser extent, civil aeronautics show, with clarity, the inefficiencies and limitations that seriously hamper sustained national development in the region. These results are not abstract disquisitions, but concrete empirical evidence that identifies the constraints and operational failures of many agencies, preventing them from fulfilling their institutional mission.

Second, states are not impotent in overcoming this situation, but their efforts have concentrated so far in strengthening organizations directly related to their own economic survival and that of economic elites, rather than those addressing the well-being of the general population. This is the reason why governments have managed to promote increasingly efficient stock exchanges and create, in a relatively short period, powerful tax agencies, while public hospitals and postal offices have been allowed to languish or even disappear. These differences are not captured by a single national indicator of institutional quality. They pertain to intranational dynamics influenced by history, culture and politics. Proactivity, the necessary condition identified by the preceding analysis, is far more common among 'clients' of the tax authority than among those of the public health service or the postal system. In all these cases, organizations should reach out to their respective clienteles, but they do so uniformly only when core interests of the state are at stake.

\subsection{National differences}

A final look at Tables 2 and 3 brings forth a second important point. Despite the historical and cultural similarities of these countries, significant differences exist in the calibre and developmental capacity of their institutions. Such differences are not drawn from single-aggregate reputational scores, but emerge from the detailed studies undertaken as part of this project. Overall, Chile appears to be in the best situation: all the organizations studied in that country were ranked as institutionally adequate and as developmental. This result confirms past descriptions of Chile as the 'success story' in Latin America (Diaz, 1996; Roberts and Portes, 2006). A detailed reading of the Chilean reports balances this overall positive assessment with a nuanced account of institutional limits and failures. The histories leading to the present outcomes are not smooth 
ones; instead they are punctuated by a number of crises and barriers, often overcome at the last minute (Cereceda, 2006; Wormald and Brieba, 2010).

If Chilean institutions are comparatively the strongest in the region, Colombian ones are the weakest. Two of them actually ceased to exist in the course of the study and even those evaluated as the best overall-the stock exchange and the tax authority-were scored lower on average than their peer organizations in other countries. The rather precarious state of this country's institutions compounds the effects of the civil war and the powerful drug industry that have challenged the nation for many years. It remains an open question whether present efforts by the Colombian state and its external allies will be able to overcome these multiple challenges in the future (Rodriguez Garavito and Rodriguez Franco, 2008). As the project's team leader in that country remarked:

The dominant institutional form in Colombia is clientelism: a combination of proactivity and lack of bureaucratic rationality that, if not always leading to failed institutions, has certainly contributed to the modest performance of the Colombian economy. (Rodriguez Garavito, 2010, p. 40)

Although less consistently than Chile, Mexico approaches the institutionally adequate/developmental pole, while the remaining two countries lean in the opposite direction. The generally positive quality of Mexican institutions can be attributed to the interplay of two broad forces. First, the opening of the economy, especially after the signing of the NAFTA treaty with the USA and Canada that forced rapid reforms in its economic institutions. Second, the advent of multi-party democracy that gave greater voice to the citizenry in support of the popular achievements of the Mexican Revolution, in particular a universal and effective public health service (Centeno, 1994; Ariza and Ramirez, 2005). The present effort to save the postal system, after years of neglect, also reflects well on the elected governments' effort to strengthen public agencies serving the general public.

Though adjoining Chile and being often regarded as one of the most developed countries in Latin America, the quality of Argentina's institutions is surprisingly poor. With the exception of the Argentine Internal Revenue Service (AFIP), which has been thoroughly re-organized and modernized, the state of the other agencies leaves much to be desired, because of internal organizational weaknesses or lack of proactivity. The future of Correo Argentino (the post office) is uncertain, having bounced back and forth from private to public management. The civil aviation agency (Comando de Regiones Aereas), an island of excellence within the state apparatus in other countries, was actually disbanded in the course of the study. After a series of corruption scandals and near accidents, the agency, run by the Argentine Air Force, was closed by the president of the republic in 
2008. As seen in Table 2, the Comando scored 0s in all predictors of institutional quality, as well as in developmental capacity. Just prior to its closure, the investigator in charge concluded:

The problems denounced by external actors have been consistently minimized by the Comando which has not shown any capacity to respond, much less to anticipate problems ... there are solid indicators of technological obsolescence in civil aviation in Argentina. The lack of training and retraining of the technical personnel reveals a complete absence of flexibility and openness to innovation. (Grimson, 2008, p. 22)

\section{Conclusion}

Commenting on the 'institutional turn', development economist Gerard Roland (2004, p. 110) remarked that 'we're all "institutionalists now". This may be the case, but such consensus can hardly advance knowledge when the definition of institutions remains vague and when measurement attempts are limited to indices with nations as units of analysis. By including countries at widely different levels of economic development, such as those of northern Europe and Africa, a number of studies arrive at the tautological conclusion that the most institutionally developed nations are indeed the most developed. Moving beyond this requires both a more rigorous definition of what institutions are and studies at closer range. Such studies can advance knowledge by showing variation within nations and among those at comparable levels of development.

Our comparative study attempts to move things in this direction. It has shown that such differences exist within Latin America, whose institutional landscape is neither uniform nor random. Instead, clear patterns emerge according to identifiable combinations of factors and the variable commitment and effectiveness of states and the external actors impinging upon them. Systematic comparison of intra-national differences show a distinct rank order where economic agencies have been the beneficiaries of vigorous state reform, while those serving the general population have often been allowed to languish or even disappear. The institutional fragility of the region as a whole is punctuated by the disbanding of three of the targeted institutions in the course of this study.

Results also support the usefulness of QCA methods for the comparative analysis of organizations. In our case, they produce a plausible profile of factors defining a developmental institution, as a combination of at least some measures of internal quality with active engagement with strategic actors in their respective spheres of activity. The convergent findings based on two different methodologies indicate that it is not lack of internal cohesion or meritocratic recruitment that represents the most signal shortcomings of Latin institutions, 
but their tendency to remain insulated, failing to engage other key actors in their environment. A proactive stance towards that environment is, according to this analysis, a necessary although not sufficient criterion of an agency's quality.

Finally, results demonstrate a distinct rank order among the nations included in the study, with Chile as the most institutionally advanced, Colombia the weakest and the others in-between. These differences among countries at comparable levels of development appear more reliable than those based on reputational indices because they are based on detailed field studies founded on the same methodology and yielding comparable rankings. Overall, the study has shown that it is possible to bring down the concept of institutions from the heights of theoretical speculation to the level of concrete empirical analysis. It has shown as well that this can be done without lapsing into disparate case studies lacking generality. A mid-range comparative approach can help us achieve a more nuanced understanding of institutions and the organizations that they underlie within as well as among countries. That knowledge is necessary to guide future policies aimed at improving the developmental performance of these organizations, preventing the repeated failures of the past.

\section{Acknowledgements}

We thank Bryan R. Roberts, Michael Woolcock and Barbara Stallings for their comments on an earlier version. We also want to thank the researchers who participated in the study, they are too numerous to acknowledge individually. Their reports are cited in the below. Responsibility for the contents of this article is exclusively ours.

\section{Funding}

This study was funded by a grant from the Princeton Institute for International and Regional Research and grant 0647030 from the National Science Foundation.

\section{References}

Abolafia, M. (1996) Making Markets: Opportunities and Restraint on Wall Street, Cambridge, MA, Harvard University Press.

Acemoglu, D., Johnson, S. and Robinson, J. A. (2001) 'The Colonial Origins of Comparative Development: An Empirical Investigation', American Economic Review, 91, 13691401.

Ariza, M. and Ramirez, J. M. (2005) 'Urbanización, Mercados de Trabajo y Escenarios Sociales en el Mexico Finisecular'. In Grimson, A., Portes, A. and Roberts, B. R. (eds) Ciudades Latinoamericanas: En el Umbral de un Nuevo Siglo, Buenos Aires, Prometeo Editores, pp. 299-362. 
Balassa, B., Bueno, G. M., Kuczynski, P.-P. and Simonsen, M. H. (1986) Toward Renewed Economic Growth in Latin America, Washington, Institute for International Economics.

Cardoso, F. H. and Faletto, E. (1979) Dependency and Development in Latin America. Translated by M. M. Urquidi, Berkeley, CA, University of California Press.

Castellanos, P. L. (2008) 'La Reforma del Sistema Publico de Salud en Republica Dominicana', Final report to the project Latin American Institutions and Development: A Comparative Analysis, Center for Migration and Development, Princeton, NJ, Princeton University.

Centeno, M. A. (1994) Democracy within Reason: Technocratic Revolution in Mexico, University Park, PA, Pennsylvania State University Press.

Cereceda, E. L. (2006) 'Institucionalidad y Desarrollo: El caso de Correos de Chile', Final report to the project Latin American Institutions and Development: A Comparative Analysis, Center for Migration and Development, Princeton, NJ, Princeton University.

Cereceda, E. L., Escobar, C. and Hoffmeister, L. (2008) 'Institucionalidad, Organización, y Reforma de la Salud en Chile', Final report to the project Latin American Institutions and Development: A Comparative Analysis, Center for Migration and Development, Princeton, NJ, Princeton University.

Clegg, S. and Hardy, C. (1996) 'Organizations, Organization and Organizing'. In Clegg, S., Hardy, C. and Nord, W. (eds) Handbook of Organization Studies, London, Sage.

De Juana, C. (2006) 'Traditional Health Care Practices'. In Resendiz, R. and Richardson, C. (eds) On the Edge of the Law: Culture, Labor, and Deviance on the South Texas Border, Austin, TX, University of Texas Press, pp. 17-50.

Diaz, A. (1996) 'Chile: Hacia el Pos-Neoliberalismo?', Paper presented at the Conference on Responses of Civil Society to Neo-Liberal Adjustment, Department of Sociology, University of Texas, Austin, TX, April.

Diaz, L. M. (2006) Vida, pasion y muerte de la administración postal naciónal, Adpostal, Colombia, Working Paper 06-08e2, Center for Migration and Development, Princeton, NJ, Princeton University.

Diaz, L. M. (2008) 'La Seguridad Social en Salud de Colombia', Final report to the project Latin American Institutions and Development: A Comparative Analysis, Center for Migration and Development, Princeton, NJ, Princeton University.

DiMaggio, P. (1990) 'Cultural Aspects of Economic Action and Organization'. In Friedlander, R. and Robertson, A. F. (eds) Beyond the Marketplace, New York, NY, Aldine de Gruyter, pp. 113-136.

Dollar, D. and Kray, A. (2002) 'Institutions, Trade, and Growth', Paper prepared for the Carnegie-Rochester Series on Public Policy.

Evans, P. B. (1979) Dependent Development: The Alliance of Multinational, State, and Local Capital in Brazil, Princeton, NJ, Princeton University Press.

Evans, P. B. (1989) 'Predatory, Developmental, and Other Apparatuses: A Comparative Political Economy Perspective on the Third World State', Sociological Forum, 4, 561-587. 
Evans, P. B. (1995) Embedded Autonomy: States and Industrial Transformation, Princeton, NJ, Princeton University Press.

Evans, P. B. (2004a) 'Development as Institutional Change: The Pitfalls of Monocropping and the Potentials of Deliberation', Studies in Comparative International Development, $38,30-52$.

Evans, P. B. (2004b) 'The Challenges of the "Institutional Turn": Interdisciplinary Opportunities in Development Theory'. In Nee, V. and Swedberg, R. (eds) The Economic Sociology of Capitalist Institutions, Princeton, NJ, Princeton University Press.

Gereffi, G. (1989) 'Rethinking Development Theory: Insights from East Asia and Latin America', Sociological Forum, 4, 505-533.

Gómez, F., Angel, M. and Ruiz, M. T. (2008) 'Mexico: Servicios Medicos Publicos de Atención a Población Abierta', Final report to the project Latin American Institutions and Development: A Comparative Analysis, Center for Migration and Development, Princeton, NJ, Princeton University.

Granovetter, M. (1985) 'Economic Action and Social Structure: The Problem of Embeddedness', American Journal of Sociology, 91, 481-510.

Grief, A. (1994) 'Cultural Beliefs and the Organization of Society: A Historical and Theoretical Reflection on Collectivist and Individualist Societies', Journal of Political Economy, 102, 912-950.

Grief, A. (2006) Institutions and the Path to the Modern Economy: Lessons from Medieval Trade, Cambridge, Cambridge University Press.

Grimson, A. (2008) 'La Aviación Civil en La Argentina', Final report to the project Latin American Institutions and Development: A Comparative Analysis, Center for Migration and Development, Princeton, NJ, Princeton University.

Gurr, R. T. (1997) 'Polity II: Political Structures and Regime Change, 1800-1986', Manuscript, Department of Political Science, University of Colorado.

Gusfield, J. R. (1955) 'Social Structure and Moral Reform: A Study of the Women's Temperance Union', American Journal of Sociology, 61, 221-232.

Guzman, R. (2008) 'Recaudación y Desarrollo: Un Analisis Institucional de la Administration Tributaria de la Republica Dominicana', Final report to the project Latin American Institutions and Development: A Comparative Analysis, Center for Migration and Development, Princeton, NJ, Princeton University.

Hirschman, A. O. (1958) The Strategy of Economic Development, New Haven, CT, Yale University Press.

Hirschman, A. O. (1963) Journeys toward Progress, New York, NY, Twentieth Century Fund.

Hodgson, G. M. (2002) 'Institutional Blindness in Modern Economics'. In Hollingsworth, E. J., Hollingsworth, J. R. and Muller, K. H. (eds) Advancing Socio-economics: An Institutionalist Perspective, Lanham, MD, Rowan and Littlefield, pp. 147-170.

Hollingsworth, J. R. (2002) 'On Institutional Embeddedness'. In Hollingsworth, E. J., Hollingsworth, J. R. and Muller, K. H. (eds) Advancing Socio-economics: An Institutionalist Perspective, Lanham, MD, Rowan and Littlefield, pp. 87-107. 
Jutting, J. (2003) 'Institutions and Development: A Critical Review', Working Paper, No. 210, OECD Development Centre.

Kaufmann, D., Kray, A. and Mastruzzi, M. (2005) 'Governance Matters IV: Governance Indicators for 1996-2004', Working Paper, S3630, Washington, DC, The World Bank.

Knack, S. and Keefer, P. (1995) 'Institutions and Economic Performance: Cross-country Tests Using Alternative Institutional Measures', Economics and Politics, 7, 207-227.

Kochanowicz, J. (1994) 'Reforming Weak States and Deficient Bureaucracies'. In Nelson, J. M., Kochanowicz, J., Mizsei, K. and Muñoz, O. (eds) Intricate links: democratization and market reforms in Latin America and Eastern Europe, New Brunswick, NJ, Transaction Publishers, pp. 195-227.

La Porta, R., Lopez-de-Silanes, F., Shleifer, A. and Vishny, R. W. (1999) 'The Quality of Government', Journal of Law, Economics, and Organization, 15, 222-279.

Lujan Ponce, N. (2008) 'El Tiempo se Acabó: El Servicio Postal Mexicano en la Encrucijada de su Modernización' Final report to the project Latin American Institutions and Development: A Comparative Analysis, Center for Migration and Development, Princeton, NJ, Princeton University.

MacIver, R. M. and Page, C. H. ([1949] 1961) Society, New York, NY, Rinehart.

MacLeod, D. (2004) Downsizing the State: Privatization and the Limits of Neoliberal Reform in Mexico, University Park, PA, Pennsylvania State University Press.

Merton, R. K. ([1940] 1957) 'Bureaucratic Structure and Personality'. In Merton, R. K., (ed) Social Theory and Social Structure, 2nd edn, Glencoe, IL, Free Press, pp. 195-206.

Merton, R. K. (1968) 'Social Structure and Anomie'. In Merton, R. K. (ed) Social Theory and Social Structure, New York, Free Press, pp. 175-214.

Merton, R. K. (1987) 'Three Fragments from a Sociologist's Notebook: Establishing the Phenomenon, Specified Ignorance, and Strategic Research Materials', Annual Review of Sociology, 13, 1-28.

Meyer, J. and Boli, J. (1997) 'World Society and the Nation State', American Journal of Sociology, 103, 144-181.

Meyer, J. and Hannan, M. T. (1979) National Development and the World System: Educational, Economic, and Political Change, 1950-1970, Chicago, IL, University of Chicago Press.

Nee, V. (2000) 'The Role of the State in Making a Market Economy', Journal of Institutional and Theoretical Economics, 156, 64-88.

Nee, V. and Opper, S. (2009) 'Bureaucracy and Financial Markets', Kyklos, 62, 293-315.

North, D. C. (1990) Institutions, Institutional Change, and Economic Performance, Cambridge, Cambridge University Press.

O'Donnell, G. (1994) 'The State, Democratization, and Some Conceptual Problems'. In Smith, W. C., Acuña, C. H. and Gamarra, E. A. (eds) Latin American Political Economy in the Age of Neoliberal Reform, New Brunswick, NJ, Transaction, pp. 157-179. 
Portes, A. (1997) 'Neoliberalism and the Sociology of Development: Emerging Trends and Unanticipated Facts', Population and Development Review, 23, 229-259.

Portes, A. (2006) 'Institutions and Development: A Conceptual Re-analysis', Population and Development Review, 32, 233-262.

Portes, A. and Hoffman, K. (2003) 'Latin American Class Structures: Their Composition and Change during the Neoliberal Era', Latin American Research Review, 38, 41-82.

Powell, W. W. (1990) 'The Transformation of Organizational Forms: How Useful Is Organization Theory in Accounting for Social Change?'. In Friedland, R. and Robertson, A. F. (eds) Beyond the Marketplace, Rethinking Economy and Society, New York, NY, Aldine de Gruyter, pp. 301-329.

Ragin, C. (1987) The Comparative Method, Moving Beyond Quantitative and Qualitative Strategies, Berkeley, CA, University of California Press.

Ragin, C. (2000) Fuzzy-set Social Science, Chicago, IL, University of Chicago Press.

Ragin, C. (2004) Between Complexity and Parsimony: Limited Diversity, Counterfactual Cases, and Comparative Analysis, Paper posted at the eScholarship repository of the University of California, Department of Sociology, University of California, Los Angeles, CA, accessed at: http://repositories.cdlib.org/uclasoc/trsca/17 on July 6, 2010.

Ragin, C. (2008) Redesigning Social Inquiry: Fuzzy Sets and Beyond, Chicago, IL, University of Chicago Press.

Rauch, J. (1995) 'Bureaucracy, Infrastructure, and Economic Growth: Evidence from U.S. Cities during the Progressive Era', American Economic Review 85, 968-979.

Roberts, B. R. and Portes, A. (2006) 'Coping with the Free Market City: Collective Action in Six Latin American Cities at the End of the Twentieth Century', Latin American Research Review, 41, 57-83.

Robinson, W. (1996) Promoting Polyarchy: Globalization, U.S. Intervention, and Hegemony, Cambridge, Cambridge University Press.

Rodriguez Garavito, C. (2010) 'The Colombian Paradox: A Thick Institutionalist Analysis', Paper presented at the Conference on Latin American Institutions and Development, Center for Migration and Development, Princeton University, Princeton, NJ, April $1-3$.

Rodriguez Garavito, C. and Rodriguez Franco, D. (2008) 'Impuestos, Clientelismo y Democracia: Una Etnografia Institucional de la Administración de Impuestos de Colombia', Final report to the project Latin American Institutions and Development: A Comparative Analysis, Center for Migration and Development, Princeton, NJ, Princeton University.

Rodrik, D., Subramanian, A. and Trebbi, F. (2002) Institutions Rule: The Primacy of Institutions over Integration and Geography in Economic Development, IMF WorkingPaper WP/02/189, Washington, DC, International Monetary Fund.

Roig, A. (2008) 'La Dirección General Impositiva de la Agencia Federal de Ingresos Publicos (AFIP) de la Argentina', Final report to the project Latin American Institutions and 
Development: A Comparative Analysis, Center for Migration and Development, Princeton, NJ, Princeton University.

Roland, G. (2004). 'Understanding institutional change: Fast-moving and slow-moving institutions'. Studies in Comparative International Development 38: 109-131.

Sabel, C. (1994) 'Learning by Monitoring: The Institutions of Economic Development'. In Smelser, J. and Swedberg, R. (eds) The Handbook of Economic Sociology, Princeton, NJ, Princeton University Press and Russell Sage Foundation, pp. 137-165.

Sachs, J. (2003) 'Institutions Don't Rule: Direct Effects of Geography on Per Capita Income', NBER Working Paper W9490, New York, NY, NBER.

Sanchez Mariñez, J. (2008) 'El Correo en Republica Dominicana: Vida, Pasión y Muerte (¿y Resurrección?) de un Servicio Público', Final report to the project Latin American Institutions and Development: A Comparative Analysis, Center for Migration and Development, Princeton, NJ, Princeton University.

Scott, W. R. (1995) Institutions and Organization, Thousand Oaks, CA, Sage.

Scott, W. R. (2001) Institutions and Organizations, 2nd edn, Thousand Oaks, CA, Sage.

Selznick, P. ([1949] 1966) TVA and the Grassroots, Berkeley, CA, University of California Press.

Sen, A. (1999). Development as Freedom. New York, NY, Knopf.

Stinchcombe, A. L. (1965) 'Social Structure and Organizations'. In March, J.G. (ed.) Handbook of Organizations, Chicago, IL, Rand McNally, pp. 142-193.

Vaisey, S. (2009) 'The "Ragin" Revolution Continues', Contemporary Sociology, 38, $308-312$.

Velasco, J. L. (2008) 'Servicio de Administración Tributaria de Mexico', Final report to the project Latin American Institutions and Development: A Comparative Analysis, Center for Migration and Development, Princeton, NJ, Princeton University.

Weber, M. ([1904] 1949) The Methodology of the Social Sciences, Translated by E.A. Shils and H.A. Finch, New York, NY, The Free Press.

Williamson, J. (1994) The Political Economy of Policy Reform, Washington, DC, Institute for International Economics.

Wormald, G. and Brieba, D. (2006) 'La Bolsa de Comercio de Santiago de Chile: Un Analisis Institucional', Final report to the project Latin American Institutions and Development: A Comparative Analysis, Center for Migration and Development, Princeton, NJ, Princeton University.

Wormald, G. and Brieba, D. (2010) 'Institutional Development and Change in Chilean Market Society', Paper presented at the Conference on Latin American Institutions and Development, Center for Migration and Development, Princeton, NJ, Princeton University, April.

Wormald, G. and Cardenas, A. (2008) 'Formación y Desarrollo del Servicio de Impuestos Internos (SII) en Chile: Un Analisis Institucional' Final report to the project Latin American Institutions and Development: A Comparative Analysis, Center for Migration and Development, Princeton, NJ, Princeton University.

Zeitlin, M. (1984) The Civil Wars in Chile, Princeton, NJ, Princeton University Press. 